\title{
Voting Pattern in District of Dir: A Case Study of Three General Elections (from 2002 to 2013)
}

\author{
* Muhammad Rashid, PhD Scholar (Corresponding Author) \\ ** Dr. Husnul Amin, Associate Professor
}

\begin{abstract}
Voting pattern is one of the important themes of political science that, indicates the level of political participation of citizens in modern democracies, through the electoral process. The electoral processes have played an important role throughout history and in the overall political discourse of the modern nation-states. In this regard, this research is designed to find out the determinants of voting patterns in the two Districts of Dir. The objective of this study is to understand people's attitudes toward electoral politics and voting practices. This study will seek to respond to the query regarding the role of multiple political factors that contribute to shaping voting patterns. The nature of the study is descriptive while using quantitative data. The collected data is analyzed through statistical and interpretative methods. This research is based on the theoretical framework of sociological, psycho-social, and rational choice models that focus on the political determinants of the voting pattern in Districts of Dir
\end{abstract}

Keywords: Voting Patter, Electoral Process, Determinants, Quantitative Data, Sociological, Psychosocial, Rational Choice

\section{Introduction}

Pakistan is a country where socio-cultural, economic, and religious determinants played a vital role in shaping the voting pattern. Before partition, the Muslim League was able to secure the majority of votes in the 1946 elections and legitimized its claim of being a sole representative political party of Muslims in the subcontinent, and demanded a separate state for the Muslims. The movement succeeded and Pakistan came into being as a democratic country. Though it was decided to run the country through the democratic process but almost for three decades no proper elections were held.

In 1970, the first general elections were held in Pakistan. However, the elections failed to bring a unified and democratically elected leadership due to the electoral conflicts of the leaders from the West and East Pakistan. The crisis further aggravated as the leaders from both wings failed to get reconciled which lead to a state of civil war that ultimately resulted in the cessation of East Pakistan from the parent country. The crises surrounding the results of Pakistan's second national elections in 1977 led to the second military takeover by General Zia-ul-Haq which lasted for eleven years (Wilder, 1999). The period from 1985 to 1997 experienced five general elections (1985, 1988, 1990, 1993 and 1997) (Wilder, 1999) but no elected government was able to complete its constitutional term and was dismissed by civilian Presidents by using Article 2 (B) of the 8th Constitutional Amendment to the Constitution of 1973 or through military indirect influence (Farmanullah, 2014).

In the 2002 general elections, the major political parties i.e. Pakistan Muslim League-Nawaz and Pakistan People Party were excluded from the election process (Farmanullah, 2014). The new democratic leadership that emerged at the national level led to the creation of an alliance of sixreligion political parties called Mutahida Majlis-i-Amal Pakistan (MMA) which formed government in Khyber Pakhtunkhwa set on opposition benches at the center (Khan, 2011). Similarly, the qualification implemented through the condition of Graduation as qualification to the legislature by the Musharraf regime for contesting elections excluded many seasoned politicians from the election process.

Unlike other provinces, the determinants of the voting pattern in KP remained different and unpredictable throughout the elections from 2002 to 2013, where MMA, ANP (Awami National

\footnotetext{
* Department of Politics \& IR, International Islamic University Islamabad

Email: m.rashid85@gmail.com

** Fulbright Fellow, South Asia Center, University of Pennsylvania, United States of America

Email: husnulamin@ hotmail.com
} 
Party), and PTI (Pakistan Tehreek Insaf) ran the province consecutively. But the case of the two districts of Dir was entirely different from the rest of the province as the pattern persisted unchanged from the very beginning.

Although in academia the socio-political and economic factors that determine the voting pattern in Districts of Dir are generally unnoticed. This research is designed to find out the determinants of voting behavior in KP with a particular focus on the Districts of Dir in the last three elections me .e.2002, 2008, and 2013.

\section{Objective of the Study}

To understand people's attitudes toward electoral politics and voting practices

\section{Conceptual framework}

The scientific approaches for conducting this study are the sociological model, psycho-social model, and rational choice theory. These three models are framed for investigating the determinants which influence sociological voting pattern. The sociological model, which is also known as the school of Columbia, the Sociological theory of voting behavior focuses on the individual and the social structure surrounding the individual. Thus, it focuses on the effects of variables such as social class, religion, ethnicity, language, and rural-urban divisions (Scott \& Marshall, 2009).

The Psychosocial model of voting behavior known as the School of Michigan, highlights the importance and influence of political factors in voting behavior. It also links voting decisions to the psychological predispositions of voters like their party identifications and perceptions about the candidates etc.(Scott \& Marshall, 2009). The theory identifies six primary psychological factors that may influence voters' decision-making process. These factors include party identification, concerns with issues, personal attachment to candidates, conformity to the groups' standards, sense of efficacy, and sense of civic obligation to vote (Aiba, 2003).

Rational Choice Theory is also called the School of Rochester or model of economic voting (Antunes, 2010). The rational choice model considers individuals' voting behavior as an outcome of cost-benefit analysis before casting vote. In this regard, voters look at issues addressed, and policies supported by various political parties and candidates (Scott \& Marshall, 2009). This model explains voting patterns in economic terms (Antunes, 2010).

\section{Voting Behavior Approaches Model (Diagram)}
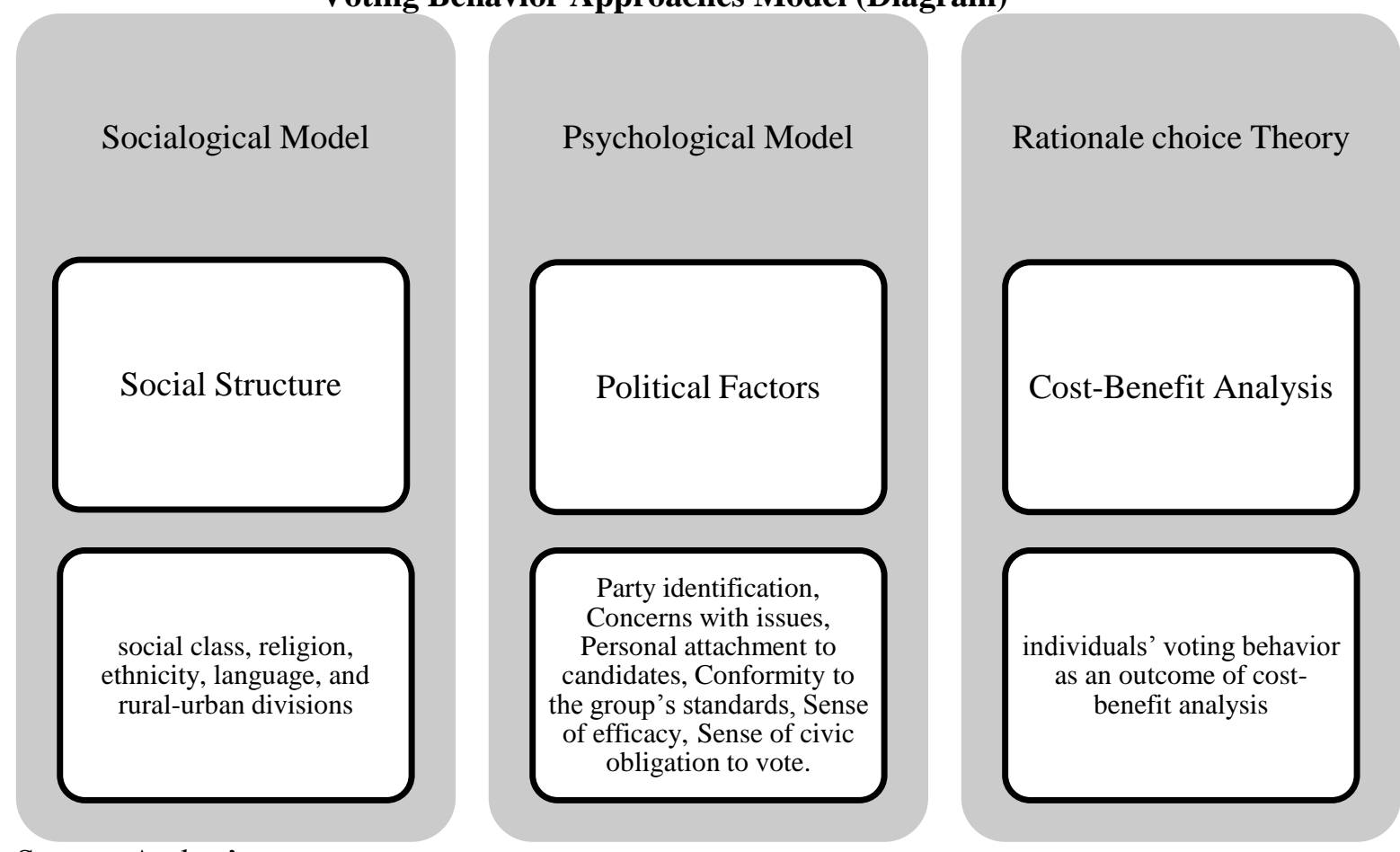

Source: Author's construct

\section{Methodology}

This study employed a quantitative method in getting the data for academic inquiring about studying the voting pattern. The quantitative analysis is based on the primary data acquired from the field survey in both districts of Dir. In this survey, the researcher used an organized questionnaire, which 
consists of closed-ended questions in which the respondents were asked to select an answer from the few options of their choice provided by the researcher. A questionnaire is a research tool comprising a set of questions that aims at collecting information from respondents (Gault, RH 1907). A good questionnaire is one that helps in attaining the research objectives, provides complete and accurate findings based on the information, which is also easy for both interviewers and respondents to complete.

\section{Voting patterns' findings of data are described in the following tabulation}

The following findings are the product of the survey, conducted from the 896 samples from the population of the registered voters in Districts of Dir. This data has been collected through the nonprobability sampling method. The rationale behind this method is the geographical location of Districts of Dir, which makes the access impossible to each corner of it, and the traditional norms prevailing there are not allowing men to meet with female directly for any academic pursuit. Therefore this method has been adopted to make this study possible.

\section{Respondent's Interests in Politics}

The results of this table show, that most of the residents of Dir are interested in politics. The more individuals who partake in a democracy, the more democratic it becomes (Tocqueville, 1839). Russell $\mathrm{J}$ Dalton argues that the problem lies with the association gap: the well-off are more involved in policy, while the underprivileged vote less and deprived of the means to lobby for the change (Russell J Dalton, 1988). Therefore the high number of participants in the electoral process is a good sign for the political system.

Are you interested in politics?

\begin{tabular}{|c|c|c|c|c|c|}
\hline \multirow{2}{*}{ Valid } & 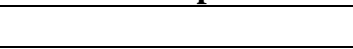 & Frequency & Percent & Valid Percent & Cumulative Percent \\
\hline & No & 6 & .7 & .7 & .7 \\
\hline & To large extent agree & 291 & 32.5 & 32.5 & 33.1 \\
\hline & To smaller extent agree & 89 & 9.9 & 9.9 & 43.1 \\
\hline & To some extent agree & 508 & 56.7 & 56.7 & 99.8 \\
\hline & Unknown & 2 & .2 & .2 & 100.0 \\
\hline & Total & 896 & 100.0 & 100.0 & \\
\hline
\end{tabular}

Source: Author's construct

When the participants were asked about their interest in politics, a very huge number of the respondents were affirmative. Accumulating the results of the options, like, to a great extent, to some extent and a small extent aggregated $99 \%$. It means that $99 \%$ of the respondents are interested in politics. To see the results in its detail, they show that $32 \%$ of respondents having an interest in politics to a great extent, while $56 \%$ to some extent and $9 \%$ to a small extent.

\section{The Main Source of Information about Politics}

The sources of information have a great role in the whole political structure. Modern media have a great impact on democratic governance and political practices. They have fundamentally reformed the conduct in which government organizations function and political leaders interconnect. They also redefined the system in which elections are contested, and the way citizens engage in politics (R. Davis, O, Diana, 1998).

What is your main source of information about politics?

\begin{tabular}{llrrr}
\hline & Frequency & Percent & Valid Percent & Cumulative Percent \\
\hline Valid & Family & $\mathbf{4 . 1}$ & $\mathbf{5 . 1}$ & $\mathbf{5 . 1}$ \\
News paper & $\mathbf{1 2 7}$ & $\mathbf{1 4 . 2}$ & $\mathbf{1 4 . 2}$ & $\mathbf{1 9 . 3}$ \\
Political peer or party & $\mathbf{2 7}$ & $\mathbf{3 . 0}$ & $\mathbf{3 . 0}$ & $\mathbf{2 2 . 3}$ \\
Radio & $\mathbf{1 2}$ & $\mathbf{1 . 3}$ & $\mathbf{1 . 3}$ & $\mathbf{2 3 . 7}$ \\
Social Media & $\mathbf{5 4 7}$ & $\mathbf{6 1 . 0}$ & $\mathbf{6 1 . 0}$ & $\mathbf{8 4 . 7}$ \\
TV & $\mathbf{1 3 5}$ & $\mathbf{1 5 . 1}$ & $\mathbf{1 5 . 1}$ & $\mathbf{9 9 . 8}$ \\
Unknown & $\mathbf{2}$ & .2 & .2 & $\mathbf{1 0 0 . 0}$ \\
Total & $\mathbf{8 9 6}$ & $\mathbf{1 0 0 . 0}$ & $\mathbf{1 0 0 . 0}$ & \\
\hline
\end{tabular}

Source: Author's construct

When the respondents were inquired about their main source of information about politics, a very huge percentage $61 \%$ said that they rely on social media. While $15 \%$ said they used TV to be updated on political affairs, and $14.2 \%$ said they preferred new paper for the political news. 


\section{The Basic Motive for Participation in the Voting Process}

People vote mostly, since they are motivated by civic duty, or due to their affiliation to a specific political party, or even some do it because of the religious grounds. In these findings, the majority of people are motivated due to civic duty, while religious reasons and political affiliation follow it with the same number. The social rewards and retributions related to voting. The monitoring by the political class within the community plays an important role in this regard, sometimes voter mobilization making electoral competition, which inspires others to partake in the electoral process (A, S. Najeeb, and L. Charles, 2013).

In your opinion, what is the basic motive for the participation in the voting process?

\begin{tabular}{|c|c|c|c|c|c|}
\hline & & Frequency & Percent & $\begin{array}{c}\text { Valid } \\
\text { Percent }\end{array}$ & $\begin{array}{c}\text { Cumulative } \\
\text { Percent }\end{array}$ \\
\hline \multirow[t]{9}{*}{ Valid } & $\begin{array}{l}\text { Because the candidate or party highlighted } \\
\text { important issues }\end{array}$ & 58 & 6.5 & 6.5 & 6.5 \\
\hline & Due to the affiliation of the political party & 246 & 27.5 & 27.5 & 33.9 \\
\hline & On the basis of religion & 244 & 27.2 & 27.2 & 61.2 \\
\hline & Other & 4 & .4 & .4 & 61.6 \\
\hline & Relation with the candidate & 14 & 1.6 & 1.6 & 63.2 \\
\hline & To perform civic duty & 313 & 34.9 & 34.9 & 98.1 \\
\hline & To serve personal interest & 16 & 1.8 & 1.8 & 99.9 \\
\hline & Unknown & $\mathbf{1}$ & .1 & .1 & 100.0 \\
\hline & Total & 896 & 100.0 & 100.0 & \\
\hline
\end{tabular}

Source: Author's construct

Participants responded to the question, asked about the basic motives for their participation in politics. $34 \%$ respondent said that they participated in this process to perform the civic duty. While $27 \%$ said that, they were taking part in this process due to the affiliation with the political party. Interestingly $27 \%$ said that they did it on religious grounds.

Do you think that your vote can make any change?

\begin{tabular}{llrrrr}
\hline & Frequency & Percent & Valid Percent & Cumulative Percent \\
\hline Valid & $\mathbf{1 3 3}$ & $\mathbf{1 4 . 8}$ & $\mathbf{1 4 . 8}$ & $\mathbf{1 4 . 8}$ \\
& I Don't Know & $\mathbf{5}$ & $\mathbf{. 6}$ & $\mathbf{. 6}$ & $\mathbf{1 5 . 4}$ \\
No- & $\mathbf{2 5 1}$ & $\mathbf{2 8 . 0}$ & $\mathbf{2 8 . 0}$ & $\mathbf{4 3 . 4}$ \\
To large extent agree & $\mathbf{2 2}$ & $\mathbf{2 . 5}$ & $\mathbf{2 . 5}$ & $\mathbf{4 5 . 9}$ \\
To smaller extent agree & $\mathbf{4 8 5}$ & $\mathbf{5 4 . 1}$ & $\mathbf{5 4 . 1}$ & $\mathbf{1 0 0 . 0}$ \\
To some extent agree & $\mathbf{8 9 6}$ & $\mathbf{1 0 0 . 0}$ & $\mathbf{1 0 0 . 0}$ & \\
Total & & & &
\end{tabular}

Source: Author's construct

Participants were asked whether they think that their vote could make any change. The majority $54 \%$ of the respondents answered affirmatively in the category of 'to some extent agree', while $28 \%$ were affirmative to a great extent. Accumulatively $82 \%$ of respondents were positive about the change based on their votes.

Do you think that elections held in Pakistan are usually free and fair?

Transparency is a significant norm for valid elections. A transparent electoral procedure is one in which each phase is observable and open to inspection by stakeholders like, political parties, candidates, electoral watchdogs, and voters, etc., who can verify the process autonomously. Conducting free and fair elections and ensuring transparency in the electoral process helps establish trust and public confidence among the voters, as they have a procedure to validate the accuracy of the results whether they reflect the will of the people in its true spirits (AGORA, 2017).

\section{Do you think that elections held in Pakistan are usually free and fair?}

\begin{tabular}{llrrrr}
\hline & Frequency & Percent & Valid Percent & Cumulative Percent \\
\hline Valid & $\mathbf{2 5}$ & $\mathbf{2 . 8}$ & $\mathbf{2 . 8}$ & $\mathbf{2 . 8}$ \\
& I Don't Know & $\mathbf{2 3 2}$ & $\mathbf{2 5 . 9}$ & $\mathbf{2 5 . 9}$ & $\mathbf{2 8 . 7}$ \\
No & $\mathbf{4 1}$ & $\mathbf{4 . 6}$ & $\mathbf{4 . 6}$ & $\mathbf{3 3 . 3}$ \\
To large extent agree & $\mathbf{5 1 3}$ & $\mathbf{5 7 . 3}$ & $\mathbf{5 7 . 3}$ & $\mathbf{9 0 . 5}$ \\
To some extent agree & $\mathbf{8 5}$ & $\mathbf{9 . 5}$ & $\mathbf{9 . 5}$ & $\mathbf{1 0 0 . 0}$ \\
Yes & $\mathbf{8 9 6}$ & $\mathbf{1 0 0 . 0}$ & $\mathbf{1 0 0 . 0}$ & \\
Total & & &
\end{tabular}

Source: Author's construct

In response to the above question about the transparency of the election being held in Pakistan, 57\% which forms the majority of the respondents, expressed their willingness that the elections were 
free and fair, 4\% to the larger category, and 9\% agree that elections are free and fair. While $26 \%$ still believe that the elections held in Pakistan are not free and fair.

For which party (or electoral coalition) did you vote in the 2002 elections?

The majority of respondents supported MMA (Mutahida Majlas e Amal) in 2002. This was the case in the whole NWFP (Northwest Frontier Province). As this pattern is seen in sociological order, where religion has an impact on voters. Since MMA was an alliance of various religious parties so they influenced such voters across the province generally and in the Districts of Dir particularly.

For which party (or electoral coalition) did you vote in the 2002 elections?

\begin{tabular}{llrrrr}
\hline & Frequency & Percent & Valid Percent & Cumulative Percent \\
\hline Valid & ANP & $\mathbf{1 3}$ & $\mathbf{1 . 5}$ & $\mathbf{1 . 5}$ & $\mathbf{1 . 5}$ \\
Independent candidate & $\mathbf{1}$ & .1 & .1 & $\mathbf{1 . 6}$ \\
MMA & $\mathbf{3 4 5}$ & $\mathbf{3 8 . 5}$ & $\mathbf{3 8 . 5}$ & $\mathbf{4 0 . 1}$ \\
PMLN & $\mathbf{5}$ & .6 & .6 & $\mathbf{9 3 . 4}$ \\
PPP & $\mathbf{5 0}$ & $\mathbf{5 . 6}$ & $\mathbf{5 . 6}$ & $\mathbf{9 9 . 0}$ \\
PTI & $\mathbf{5}$ & .6 & .6 & $\mathbf{9 9 . 6}$ \\
QWP & $\mathbf{4}$ & .4 & .4 & $\mathbf{1 0 0 . 0}$ \\
\hline
\end{tabular}

Source: Author's construct

Participants were asked, that in 2002 general election to which party they have voted. The majority of the participants i.e. $38 \%$ said that they have voted MMA, only 5\% voted PPP.

For which party (or electoral coalition) did you vote in the 2008 elections?

\begin{tabular}{llrrrr}
\hline & Frequency & Percent & Valid Percent & Cumulative Percent \\
\hline Valid & ANP & $\mathbf{3 3}$ & $\mathbf{3 . 7}$ & $\mathbf{3 . 7}$ & $\mathbf{3 . 7}$ \\
& Boycott & $\mathbf{9 1}$ & $\mathbf{1 0 . 2}$ & $\mathbf{1 0 . 2}$ & $\mathbf{1 3 . 8}$ \\
Independent candidate & $\mathbf{3}$ & .3 & .3 & $\mathbf{1 4 . 2}$ \\
JUIF & $\mathbf{1 1 7}$ & $\mathbf{1 3 . 1}$ & $\mathbf{1 3 . 1}$ & $\mathbf{2 7 . 2}$ \\
No & $\mathbf{4}$ &. $\mathbf{4}$ & .4 & $\mathbf{7 9 . 8}$ \\
PMLN & $\mathbf{2 2}$ & $\mathbf{2 . 5}$ & $\mathbf{2 . 5}$ & $\mathbf{8 2 . 3}$ \\
PPP & $\mathbf{1 2 0}$ & $\mathbf{1 3 . 4}$ & $\mathbf{1 3 . 4}$ & $\mathbf{9 5 . 6}$ \\
PTI & $\mathbf{7}$ & .8 & .8 & $\mathbf{9 6 . 4}$ \\
QWP & $\mathbf{3 2}$ & $\mathbf{3 . 6}$ & $\mathbf{3 . 6}$ & $\mathbf{1 0 0 . 0}$ \\
\hline
\end{tabular}

Source: Author's construct

Respondents were asked for which party they had voted in the 2008 general election? $13 \%$ said PPP, 13\% said JUIF (Jamiat Ulma-e-Islam Fazalurahman), 4\% ANP, while, 10\% of respondents said that they have boycotted. JI has boycotted these elections, so the table does not show its manifestation in the 2008 elections.

For which party (or electoral coalition) did you vote in the 2013 elections?

In the following table, the results show that JI (Jamaat-e-Islami) has the majority of votes in the 2013 elections. The role of JI has been dominant throughout the elections since 1970. However, PPP and then somehow ANP remained its main rival in some areas.

For which party (or electoral coalition) did you vote in the 2013 elections?

\begin{tabular}{llrrrr}
\hline & Frequency & Percent & Valid Percent & Cumulative Percent \\
\hline Valid & ANP & $\mathbf{3 2}$ & $\mathbf{3 . 6}$ & $\mathbf{3 . 6}$ & $\mathbf{3 . 6}$ \\
& Independent candidate & $\mathbf{8}$ & $\mathbf{9}$ & $\mathbf{9}$ & $\mathbf{4 . 5}$ \\
JI & $\mathbf{3 1 4}$ & $\mathbf{3 5 . 0}$ & $\mathbf{3 5 . 0}$ & $\mathbf{3 9 . 5}$ \\
JUIF & $\mathbf{9 2}$ & $\mathbf{1 0 . 3}$ & $\mathbf{1 0 . 3}$ & $\mathbf{4 9 . 8}$ \\
PMLN & $\mathbf{2 2}$ & $\mathbf{2 . 5}$ & $\mathbf{2 . 5}$ & $\mathbf{7 3 . 4}$ \\
PPP & $\mathbf{8 2}$ & $\mathbf{9 . 2}$ & $\mathbf{9 . 2}$ & $\mathbf{8 2 . 6}$ \\
PTI & $\mathbf{1 1 0}$ & $\mathbf{1 2 . 3}$ & $\mathbf{1 2 . 3}$ & $\mathbf{9 4 . 9}$ \\
QWP & $\mathbf{4 6}$ & $\mathbf{5 . 1}$ & $\mathbf{5 . 1}$ & $\mathbf{1 0 0 . 0}$ \\
\hline
\end{tabular}

Source: Author's construct

Respondents were asked for which party they had voted in the 2013 general elections? The majority $35 \%$ said they have voted JI, while $12 \%$ supported PTI and only $9 \%$ voted PPP.

It is important to vote based on affiliation with a political party

Since the researcher has also applied the psycho-social model in this study. A related question has been asked from the participants of the survey, whether they prefer party affiliation during vote casting majority are affirmative in their responses. 
It is important to vote based on affiliation with a political party.

\begin{tabular}{llrrrr}
\hline & Frequency & Percent & Valid Percent & Cumulative Percent \\
\hline Valid & Disagree & $\mathbf{5 6}$ & $\mathbf{6 . 3}$ & $\mathbf{6 . 3}$ & $\mathbf{6 . 3}$ \\
& I Don't Know & $\mathbf{1 9}$ & $\mathbf{2 . 1}$ & $\mathbf{2 . 1}$ & $\mathbf{8 . 4}$ \\
Strongly agree & $\mathbf{4 0 3}$ & $\mathbf{4 5 . 0}$ & $\mathbf{4 5 . 0}$ & $\mathbf{5 3 . 3}$ \\
To some extent agree & $\mathbf{4 1 1}$ & $\mathbf{4 5 . 9}$ & $\mathbf{4 5 . 9}$ & $\mathbf{9 9 . 2}$ \\
To some extent disagree & 7 & $\mathbf{8}$ & $\mathbf{. 8}$ & $\mathbf{1 0 0 . 0}$ \\
Total & $\mathbf{8 9 6}$ & $\mathbf{1 0 0 . 0}$ & $\mathbf{1 0 0 . 0}$ & \\
\hline
\end{tabular}

Source: Author's construct

Participants were told that, was it important to vote based on political party affiliation. The majority of $45 \%$ of the respondents said that they strongly agreed with this statement, again $45 \%$ said that to some extent they agree with this statement. It becomes $90 \%$ which is a huge number that believes that party affiliation is important.

It is more important to vote based on religion?

A sociological related question when they have been asked, whether they consider religion important during the vote casting, the majority have agreed to this statement, with a small opposition i.e. 7.4\% who disagree with this statement.

It is more important to vote based on religion?

\begin{tabular}{llrrrr}
\hline & Frequency & Percent & Valid Percent & Cumulative Percent \\
\hline Valid & Disagree & $\mathbf{6 6}$ & $\mathbf{7 . 4}$ & $\mathbf{7 . 4}$ & $\mathbf{7 . 4}$ \\
Strongly agree & $\mathbf{6 1 4}$ & $\mathbf{6 8 . 5}$ & $\mathbf{6 8 . 5}$ & $\mathbf{7 5 . 9}$ \\
To some extent agree & $\mathbf{2 0 8}$ & $\mathbf{2 3 . 2}$ & $\mathbf{2 3 . 2}$ & $\mathbf{9 9 . 1}$ \\
To some extent disagree & $\mathbf{8}$ & .9 & $\mathbf{. 9}$ & $\mathbf{1 0 0 . 0}$ \\
Total & $\mathbf{8 9 6}$ & $\mathbf{1 0 0 . 0}$ & $\mathbf{1 0 0 . 0}$ & \\
\hline
\end{tabular}

Source: Author's construct

Again the respondents were asked that is it more important to consider religion during vote casting. This time $68.45 \%$ majority said that they strongly agreed with this statement, while $23 \%$ said that they agreed with this statement to some extent. But $7.4 \%$ said that they do not agree with this statement, which means they do not consider religion during voting casting.

It is more important to vote based on national and regional development.

Respondents were asked whether they consider the rational choice model during vote casting. The question was about the development which supports the rational choice theory. In this regard surprisingly $97 \%$ of respondents agreed to this statement.

It is more important to vote based on national and regional development.

\begin{tabular}{llrrrr}
\hline & Frequency & Percent & Valid Percent & Cumulative Percent \\
\hline Valid & Disagree & $\mathbf{9}$ & $\mathbf{1 . 0}$ & $\mathbf{1 . 0}$ & $\mathbf{1 . 0}$ \\
I Don't Know & $\mathbf{8}$ & $\mathbf{. 9}$ & $\mathbf{. 9}$ & $\mathbf{1 . 9}$ \\
Strongly agree & $\mathbf{4 7 2}$ & $\mathbf{5 2 . 7}$ & $\mathbf{5 2 . 7}$ & $\mathbf{5 4 . 6}$ \\
To some extent agree & $\mathbf{3 9 1}$ & $\mathbf{4 3 . 6}$ & $\mathbf{4 3 . 6}$ & $\mathbf{9 8 . 2}$ \\
To some extent disagree & $\mathbf{1 6}$ & $\mathbf{1 . 8}$ & $\mathbf{1 . 8}$ & $\mathbf{1 0 0 . 0}$ \\
Total & $\mathbf{8 9 6}$ & $\mathbf{1 0 0 . 0}$ & $\mathbf{1 0 0 . 0}$ & \\
\hline
\end{tabular}

Source: Author's construct

Respondents were asked whether they think about this statement, that it is more important to vote based on national and regional development. 53\% of the respondent said that they strongly agreed with this statement, while $44 \%$ said that they agreed with this statement to some extent.

What do you think is more important to be considered during vote casting?

In this category all three models mentioned all together, this was happened on the purpose, to know that comparatively which model is adopted. So, in this case, most participants agreed with the sociological model, this means that when respondents agree with other models they do not necessarily take them comparatively, but simultaneously. In the discourse of voting behavior about splits, there are many interesting aspects and factors to be observed. The three cleft based voting factors mainly considered are class, gender, and religion. Religion is frequently a factor that influences political behavior especially the choice of choosing a political party. In recent times this voting cleft has moved away from concerning religious issues to now have a greater emphasis on religious vs nonreligious (C. Brook, 2006). 


\begin{tabular}{llrrrr}
\multicolumn{6}{c}{ What do you think is more important to be considered during vote casting? } \\
\hline \multicolumn{7}{c}{} & Frequency & Percent & Valid Percent & Cumulative Percent \\
\hline Valid & Development & 141 & 15.7 & 15.7 & 15.7 \\
Personal or family interests & 11 & 1.2 & 1.2 & $\mathbf{1 7 . 0}$ \\
Political affiliation & 137 & 15.3 & $\mathbf{1 5 . 3}$ & $\mathbf{3 2 . 3}$ \\
Relation with the candidate & 3 & .3 & .3 & $\mathbf{3 2 . 6}$ \\
Religion & $\mathbf{3 0 3}$ & $\mathbf{6 7 . 3}$ & $\mathbf{6 7 . 3}$ & $\mathbf{9 9 . 9}$ \\
Talented candidate & 1 & .1 & .1 & $\mathbf{1 0 0 . 0}$ \\
Total & $\mathbf{8 9 6}$ & $\mathbf{1 0 0 . 0}$ & $\mathbf{1 0 0 . 0}$ & \\
\hline
\end{tabular}

Source: Author's construct

Participants were asked about multiple options that could influence their consideration during vote casting. The majority of them i.e. $67 \%$ said that religion should be taken into the consideration during vote casting, while $15 \%$ of respondents said that political affiliation was more important and $15.7 \%$ was giving preference to the development.

\section{Application of different models in the general elections}

To have predictions about behavior regarding a voting choice, many features such as gender, traditions, or beliefs must be considered. Additionally, a more academic method can be taken when viewing electoral patterns, such as interests, religion, and party affiliation etc. which impact voters' electoral behavior. The effect of these influences on voting behavior is best understood through voting behavior theories. The following three models applied in this study to scientifically investigate and explore the key determinants that influence voting patter in Districts of Dir. The table shows its numerical impact in percentages, which quantify the prevailing nature of the models. Various norms links with these three models like the Sociological model focuses on the effects of variables such as social class, religion, ethnicity, language, and rural-urban divisions. Those who are inspired by these sociological norms, tabulated in this category. While the Psychosocial model of voting behavior links voting decisions to the psychological predispositions of voters like their party identifications and perceptions about the candidates etc.(Scott \& Marshall, 2009). The Rational Choice Theory also called the model of economic voting, considers individuals' voting behavior as an outcome of costbenefit analysis before casting vote. In this regard, voters look at issues addressed, and policies supported by various political parties and candidates (Antunes, 2010).

\begin{tabular}{llll}
\hline Election & Sociological Model & Psycho-Social Model & Rational-Choice Model \\
\hline $\mathbf{2 0 0 2}$ & 32.8 & 12.4 & .6 \\
$\mathbf{2 0 0 8}$ & $23 \%$ & $17 \%$ & $8 \%$ \\
$\mathbf{2 0 1 3}$ & $25 \%$ & $37 \%$ & $16 \%$ \\
\hline
\end{tabular}

Source: Author's construct

According to the survey findings, the sociological model impact more voters comparatively. This means that social class, religion, ethnicity, language, and rural-urban divisions, etc. are considered more important in terms of voting casting. Secondly, psycho-social factors like, party identification, concerns with issues, personal attachment to candidates, conformity to the group's standards, sense of efficacy, sense of civic obligation to vote, influence voters patterns. Thirdly, factors like individuals' voting behavior as an outcome of cost-benefit analysis have an impact on voting patterns.

\section{Conclusion}

From the perspective of inquiring the determinants of voter pattern in developing democracy, this research is a substantial study, based on the sociological, psycho-social, and rational choice perspectives. The researcher has found that issues such as religion, race, gender; and other social affiliations, still prevailing have a significant role and impact on voters' choice. Voters' behavior in Districts of Dir is largely determined by social factors, but simultaneously the rational choices, such as education, health, and national and regional development policies of political parties along also influence the voting pattern. Though all models have some impact on influencing voting determinants, the still sociological model has a dominant role. More specifically, this research has found that the role of religion is prevailing, especially when it comes to relative preferences in electoral politics. Due to this reason, that, mostly in general elections held in these districts, religious parties played a dominant role against other rival parties in terms of getting votes. This research will help those who are engaged in the studies of voting patterns and behavior about the applied models in this field. This research also finds that Districts of Dir still have some traditional norms and values which have a phenomenal impact on people's political choices. 


\section{References}

A, S. Najeeb, and L. Charles. (2013). "Why People Vote: Ethical Motives and Social Incentives." American Economic Journal: Microeconomics,

Agora moderator (2017). "The Role of Elections in strengthening democracy principles and values"

Aiba, J. (2003). Reviewing the Theories of Voting Behavior. Memoirs of Nara University, 283-304.

Antunes, R. (2010). Theoretical models of voting behavior. Exedra, 145-170.

Barth, F. (1969). Ethnic Groups and Boundaries: The Social Organization of Cultural Difference. London: George Allan \&Unwin.

C. Brooks, P. Nieuwbeerta., and J. Manza., (2006). "Cleavage based voting behavior in crossnational perspective: Evidence from six postwar democracies". Social Science Research, 35, 88-128, 35, 88. DOI: https://doi.org/10.1016/j.

Dalton, R, J, (1988) "Dalton Chatham House Publishers, Tocqueville, de A, (1839). "Democracy in America" London: Saunders and Otley.

Farmanullah. (2014). Voting Behavior in Pakistan: (A Case Study of Khyber Pakhtunkhwa in 2008 General Elections) (Unpublished Ph.D. Dissertation). Pakistan Study Centre, University of Peshawar.

https://agora-parl.org/interact/blog/role-elections-strengthening-democracy-principles-and-values retrieved on 05.23.2020

Khan, K. A. (2011). 2002 Elections in Pakistan: A Reappraisal. Journal of Political Studies, 18 (01), 93-108.

R. Davis, O, Diana, (1998). "New Media and American Politics”, New York: Oxford University Press.

Scott, J., \& Marshall, G. (Eds.). (2009). A dictionary of sociology. Oxford University Press, USA.

Wilder, A. R. (1999). The Pakistani Voter: Electoral Politics and Voting Behavior in Punjab. Lahore: OUP Pakistan. 